\title{
Pervious concrete: study of dosage and polypropylene fibers addiction
}

\section{Concretos drenantes: estudo de dosagem e adição de fibras de polipropileno}

S. E. PILS a

silvio@unochapeco.edu.br https://orcid.org/0000-0003-0361-7658

P. OLIVEIRA a,b poliveira@unochapeco.edu.br https://orcid.org/0000-0001-8835-6324

F. REGOSO a felipe_regoso@unochapeco.edu.br https://orcid.org/0000-0002-0270-0495

V. A. PAULON ${ }^{c}$

vpaulon@yahoo.com.br https://orcid.org/0000-0002-1061-9902

M. F. COSTELLA ${ }^{\mathrm{b}, \mathrm{c}}$

costella@unochapeco.edu.br https://orcid.org/0000-0001-6471-9848

\begin{abstract}
The use of pervious concrete to minimize the effects caused by the impermeability of the soil as a result of increasing urbanization is an alternative that still requires further studies regarding its design and implementation. From this perspective, this paper presents a study of the characteristics of pervious concrete, including its tensile strength, compressive strength, flexural strength and the permeability coefficient, through the development of various mixtures to adjust the characteristics of the local aggregates. Eight mixtures were studied based on a reference mixture, five of which were related to the pervious concrete with the addition of finer aggregates than the reference mixture without these aggregates. Subsequently, three mixtures were studied with the inclusion of polypropylene fibers in order to analyze the effects of the addition of fibers on the properties of the pervious concrete. It is concluded that the presence of fibers changed the characteristics of the concrete, increasing its strengths while achieving a good permeability in its mixtures. An improvement in the flexural strength of the pervious concrete was observed, which is the main property to be considered for its use in pavements, without harming the permeability, which raises the possibility for its application.
\end{abstract}

Keywords: pervious concrete, tests, fibers.

\section{Resumo}

Utilizar concreto permeável para minimizar os efeitos causados pela impermeabilidade do solo causado pela crescente urbanização é uma alternativa que ainda necessita de estudos quanto à sua concepção e aplicação. Seguindo esta linha, o presente artigo apresenta um estudo das características do concreto drenante, tal como a resistência à tração, resistência à compressão, resistência à tração na flexão e coeficiente de permeabilidade, através do desenvolvimento de varios traços, para ajustar às características dos agregados locais. A partir de um traço referência, foram estudados oito traços, sendo cinco referentes ao concreto drenante com adição de agregados mais finos ao traço referência sem estes agregados. Posteriormente estudou-se três traços com a inclusão de fibras de polipropileno, com o objetivo de analisar os efeitos que a adição de fibras causa nas propriedades do concreto drenante. Concluiu-se então, que a presença das fibras alterou as características do concreto, levando o mesmo a atingir maiores resistências, aliadas a uma boa permeabilidade em seus traços, verificando-se assim a meIhoria de capacidade de resistência à tração na flexão do concreto drenante, principal propriedade para uso em pavimentos, sem prejudicar a permeabilidade e avaliando a possibilidade de aplicação do mesmo.

Palavras-chave: concreto permeável, ensaios, fibras. 


\section{Introduction}

The growth in urbanization, which leads to the increased impermeabilization of the soil as a result of the paving of streets, sidewalks and buildings, brings with it ever-increasing environmental impacts that are forcing the construction industry to find alternatives to avoid future problems, such as flooding. These covered surfaces may occupy $30 \%$ of the area of the drainage basin according to the $A B C P$ [1]. If one considers the runoff coefficient or surface runoff, according to Marchioni et al. [2], very densely constructed areas may have runoff coefficients of 0.70 to 0.95 , which means that up to $95 \%$ of rainfall creates surface runoff.

According to Merighi et al.[3], pervious concrete is an alternative that can assist in urban drainage and facilitate the direct infiltration of water into the soil. However, in Brazil, its use is still in the early stages. Its application is therefore still restricted, which can be explained by the absence of adequate knowledge in relation to the mechanical and hydraulic behavior and potential applications of this material by the designers and professionals in the field. According to the standard ACl 522R-06 [4], its typical uses include: parking lot pavements, municipal roads, sidewalks, pedestrian areas in zoos, parks and swimming pool decks, among others.

According to the standard ACl 522R-06[4], pervious concrete is typically described as open-graded, zero-slump concrete with no or little fine aggregate, a void content ranging between 18 to $35 \%$ and a compression strength between 2.8 to $28 \mathrm{MPa}$, with permeability of 0.0135 to $0.122 \mathrm{~cm} / \mathrm{s}$ (already transformed units).

For the ABNT [5], a pervious pavement on a site must have a mechanical flexural strength of at least $2.0 \mathrm{MPa}$ and a permeability of $0.100 \mathrm{~cm} / \mathrm{s}$, without considering the compression strength requirement.

Rodrigues and Montardo [6] stated that the use of plastic polypropylene fibers as reinforcements in concrete has grown in recent years in Brazil in order to improve the performance of pervious concrete. Several works have used polypropylene fibers, including dams, tunnels, bridges, irrigation channels, water and sewage treatment stations and, especially, concrete pavements and floors. Polypropylene is chemically inert, does not absorb water, does not rust, has low cost and is easy attainable. In this sense, the use of polypropylene fiber is more appropriate than the use of metallic fibers because of corrosion and the need to improve the flexural strength performance, a fundamental requirement for concrete pavements.

Many properties are changed when the cementitious matrix is reinforced with fibers, such as: workability, compressive strength, modulus of rupture (flexural strength), direct tensile strength, impact resistance, resistance to fatigue, increase in tenacity, inhibition of crack propagation. Determining the optimum content is important to increase efficiency and economy, especially regarding the main properties relevant to the intended use. In light of the scarce studies on the behavior of pervious concrete using fibers, studies of concrete mixtures with various levels of fibers have become more important, and this is one of the objectives of this work.

The post-cracking behavior will not be evaluated because the pervious concrete has a high void content, which means it is important to study the behavior of the main mechanical property of a pavement material (flexural strength). It is known, however, that the post-cracking behavior of concrete with fibers is improved with smaller cracks (Rodrigues and Montardo [6]) and the probable increase in flexural strength may explain this behavior. The study of polypropylene fibers in pervious concrete needs behavior evaluations, which is one of the objectives of this work.

In this general context, this paper seeks to observe and analyze the behavior of the mechanical properties (compression strength, split tensile strength and flexural strength) and of the permeability coefficient in different pervious concrete mixtures with and without the addition of polypropylene fibers.

\section{Theoretical framework}

According to McCain and Dewoolkar [7], the northern states of the United States have been slow in adopting the use of pervious concrete, which is a result of the lack of data on its effects and behavior. Shu et al. [8] highlight that there is a need for laboratory tests to define the appropriate mixtures, studying different types of aggregates, their particle size distribution and various additions. These issues have also been pointed out by Lian and Zhuge [9]. Regarding the permeability, the NCPTC [10] indicates values between 0.0254 and $0.6096 \mathrm{~cm} / \mathrm{s}$ to consider a concrete as pervious, while the $\mathrm{ACl} 522 \mathrm{R}-06$ standard [4] establishes values ranging from 0.0135 to $0.122 \mathrm{~cm} / \mathrm{sec}$.

Pervious concrete has some disadvantages according to the Environmental Protection Agency [11], namely: the tendency of the pavement to be obstructed by dirt if inadequately installed or maintained; the risk of considerable failure if poorly constructed or in the case of soiling; contamination of the aquifer depending on the soil conditions and the susceptibility of the aquifer; the lack of expertise of the pavement engineers. Teixeira and Fortes [12] conclude that pervious concrete has economically viable costs, but that its compression and tensile strengths are much smaller than conventional concrete. In this sense, Lian and Zhuge [9] highlight that its applications have been almost entirely restricted to pavements.

\subsection{Studies conducted on pervious concrete}

Ibrahim et al. [13] studied 24 mixtures to check the variation of the properties with the variation of different aggregate fractions, the variation in the water-cement ratio and the content of cement. They concluded that, among other factors, the maximum compression strength for mixtures without fine aggregates is achieved with levels of cement around $250 \mathrm{~kg} / \mathrm{m}^{3}$ and decreases to $75 \%$ when the ratio is reduced to $150 \mathrm{~kg} / \mathrm{m}^{3}$.

Lian and Zhuge [9] concluded that the use of fine materials with a particle size between 9.5 and $2.4 \mathrm{~mm}$ increased the strength properties of the pervious concrete. However, the use of too fine aggregates, such as active silica, does not significantly alter the strength, because very fine particles tend to segregate due to the porosity of the concrete. Batezini [14] concluded that the addition of fine aggregates in concretes for the improvement of the mechanical properties is a possibility, especially when the permeability coefficient of the mixtures has higher values. In this study, the permeability value was $0.14 \mathrm{~cm} / \mathrm{s}$ and the split tensile strength and the flexural strength ranged between 57 and $71 \%$ for the three mixtures.

Based on the development of concrete mixtures with five different aggregate particle sizes of granitic origin, Merighi et al. [3] 
aimed to find a mixture that provided good mechanical strength to be used in the paving of airport runways and roads. The best results regarding strength at 28 days was $31.6 \mathrm{MPa}$ for compression strength and 3.0 MPa for tensile strength for the mixture that used smaller aggregates than the other mixtures, a low w/c ratio, a superplasticizer additive and micro silica. However, Merighi et al. [3] stated that the use of this concrete as draining layer was not recommended because it had a permeability coefficient in the order of $10^{-3} \mathrm{~cm} / \mathrm{sec}$

The discrepancy between permeability and strength, studied by Kajio et al. [15] and Tennis et al. [16], is usually dictated by the quantity of fine aggregate used in the mixtures, with a greater quantity of these aggregates decreasing the void content, increasing strength and reducing permeability. Identifying the optimal ratio between voids, permeability and strength is one of the challenges of researchers regarding the adequate use of aggregates, and this is one of the objectives of this work.

Cosic et al. [17] studied the variation in the properties of pervious concrete as a function of the variation in the type of aggregate and its size. One of their findings was the surprising conclusion that the type of aggregate has a more significant influence on permeability than its size. Lian and Zhuge [9] also found differences in the permeability values as a function of different types of aggregates. Bonicelli et al. [18] investigated the difference in the properties of pervious concrete when different levels of concrete compaction were used, in addition to the influence of the addition of sand, and their results suggested that the addition of around $5 \%$ of the total aggregate mass as sand improved the mechanical properties, highlighting an increase of up to $75 \%$ in the tensile strength, but with a decrease in permeability, without compromising the drainage capacity of the concrete, however.

Maguesvari and Narasimha [19] studied the influence of coarse and fine aggregates on pervious concrete and concluded that the increase in fine aggregates reduced permeability, but increased the compression and flexural strength, making it a suitable material for pavements with light traffic.

\subsection{Studies of concretes with polypropylene fibers}

In a study conducted by Senisse and Dal Molin [20], three concrete mixtures were developed for each of the mixtures evaluated, using a mortar content of $55 \%$ and w/c ratios ranging between 0.34 and 0.68 . Three types of concrete were prepared: conventional concrete (reference-CC), concrete reinforced with polypropylene macro-fibers (CF) and concrete reinforced with macro-fibers and a superplasticizer additive (CFSP), with a content of $600 \mathrm{~g} / \mathrm{m}^{3}$ in fibers and $0.32 \%$ of superplasticizer in relation to the cement mass. The results showed that the inclusion of macro-fibers significantly increased the flexural strength $(39 \%$ for the CF mixture and $27 \%$ for the CFSP mixture, even though the compression strength decreased in the CF case). They also concluded that the addition of fibers in the concrete had an insignificant increase in cost (SENISSE; DAL MOLIN [20]).

Perrone et al. [21] commented in a study that the addition of nonmetallic fibers can help overcome problems with corrosion and improve the structural performance. Gesoglu et al. [22] studied the properties of pervious concrete with the addition of fibers of different types of rubber tire residues and they concluded that it is possible to obtain pervious concretes with more compression strength or better permeability depending on the characteristics of the waste, but that, on average, the concretes with the residues had worse strength properties and decreased permeability when compared to the reference mixture without residues, but the fracture energy increased with the tire residues and its use was feasible in parking areas.

Hesami et al. [23] studied the use of various materials, including glass fiber, with a content of $0.2 \%$ in pervious concrete, and they observed an increase of up to $30 \%$ in the tensile strength and of up to $64 \%$ in the flexural strength, corroborating the tendency of improved mechanical properties with the increase in the percentage of material, with a gradual decrease after the optimal percentage.

Amaral Junior [24] and Lucena [25] observed that the use of polymeric fibers usually means that there is a reduction in the axial compression strength, but the flexural strength increases.

In a study conducted by Guimarães et al. [26], the best performance for flexural strength was found with the fiber content of $1 \%$. Rehder et al. [27] also observed this fact, which may be explained because the pores are connected by fibers, with the contribution of fibers to improve the residual flexural capacity, especially at higher porosities. In this sense, this paper seeks to investigate the relationship between the use of fibers in different proportions and the behavior of pervious concrete.

\section{Methodological procedures}

One of the objectives of this work is to study concrete mixtures with the use of regional materials based on a pervious concrete without sand, and based on this verify the behavior of the mechanical and permeability properties when different levels of sand are added. The influence of the addition of non-metallic fibers, in this case polypropylene, on the cited properties, especially on flexural strength and permeability, since these are the parameters indicated by NBR 16416 (ABNT [5]), is also studied.

Based on the mixtures pre-determined by other researchers who showed reasonable results for strength and permeability (Polastre and Santos [28]; Sales [29]; Kajio et al. [15]; Tennis et al. [16]), a reference mixture (mixture $A$ ) was established containing only cement and gravel 1. Four other mixtures $(B, C, D$ and $E$ ) were then studied to verify the influence of the addition of gravel 0 and sand on the compression strength, the split tensile strength, the flexural strength and the permeability.

Six specimens (CPs) were developed for each mixture for the axial compression tests, $6 \mathrm{CPs}$ for the split tensile strength tests, $6 \mathrm{CPs}$ for the flexural strength test, with the highest value being adopted for each one of them (potential strength, since these were concretes from the same concrete batch) and $6 \mathrm{CPs}$ for the permeability tests, which adopted the means. The molding, curing and execution procedures of the specimens followed the procedures established by the Brazilian standards of the ABNT.

Subsequently, the influence of the addition of polypropylene fibers $\left(1,2\right.$ and $\left.3 \mathrm{~kg} / \mathrm{m}^{3}\right)$ to mixture $D$ (which already contained gravel 0 and sand) on the aforementioned properties was studied in three more mixtures. The contents were based on the studies of Guimarães et al. [26] and Reyes and Torres [30]. 
Table 1

Technical specifications of the Cauê cement

\begin{tabular}{|c|c|c|c|c|c|c|c|c|}
\hline \multicolumn{2}{|c|}{ Fineness } & \multirow{2}{*}{$\begin{array}{c}\text { Concrete } \\
3.06\end{array}$} & \multicolumn{2}{|c|}{ Cement time } & \multicolumn{4}{|c|}{ Compression strength (MPa) } \\
\hline $\begin{array}{c}\# 200 \\
(75 \mathrm{~mm})\end{array}$ & $\begin{array}{c}\# 300 \\
(45 \mathrm{~mm})\end{array}$ & & Start (min) & End (min) & 1 day & 3 days & 7 days & 28 days \\
\hline 2.7 & 10.7 & & 190 & 290 & 14.4 & 28.6 & 32.8 & 41.0 \\
\hline
\end{tabular}

Table 2

Characteristics of the superplasticizer additive

\begin{tabular}{ccccc}
\hline Parameter & Unit & Specification & Results & Methods \\
\hline Aspect & - & Liquid & Approved & Visual \\
Color & - & Light brown & Approved & Visual \\
$\mathrm{pH}-25^{\circ} \mathrm{C}$ & - & 3.00 to 5.00 & 4.17 & NBR 10908:2008 \\
Specific mass $-25^{\circ} \mathrm{C}$ & $\mathrm{g} / \mathrm{cm}^{3}$ & 1.062 to 1.102 & 1.082 & NBR 10908:2008 \\
Solids & $\%$ & 38.25 to 42.75 & 39.92 & NBR 10908:2008 \\
\hline
\end{tabular}

When there were significant differences between the expected and obtained values of the properties, the tests were redone to check if it was a trend or a simple error of procedure, and in the case of mixture $\mathrm{D}$, an error in the concrete batch development procedure of the initial study was found.

The mechanical properties studied are the most significant for pervious concrete, but the effect of concrete compaction, the behavior under cyclic actions, abrasion wear and other factors may also deserve specific studies when applying these concretes to light traffic pavements.

\subsection{Characterization of materials}

The cement used for the tests was CP II-E in bulk. No laboratory tests were performed for the cement, and the technical specifications provided by the manufacturer were used as in Table 1.

For the medium sand coming from the União da Vitória region, characterization assays were performed in the laboratory regarding the bulk density, fineness module and maximum diameter of the fine aggregate.

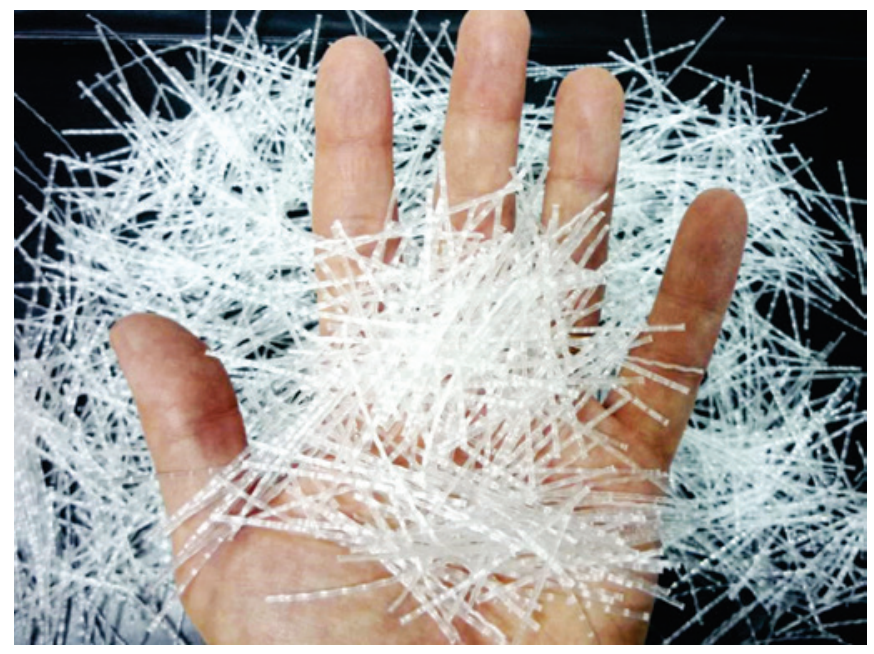

Figure 1

Polypropylene macro-fibers used
For the gravel 0 and gravel 1 , both of basaltic origin and produced in a crusher located in Cordilheira Alta - SC, the bulk density, fineness module and maximum diameter of the aggregate were determined.

The additive used was the Superplasticizer MAXIFLUID 900. Table 2 shows the data of the analysis of the additive as provided by the manufacturer, since no laboratory tests were performed. The quantity of additive used for all traits was $1 \%$ in relation to the cement mass, according to the instructions of the manufacturer.

The polypropylene fibers and their specifications were supplied by a company located in São José-SC:

- Alkali resistant;

Length: $50 \mathrm{~mm}$;

27,000 fibers per kg;

- Tensile strength of $350 \mathrm{MPa}$ (per filament);

- Twist - anchoring;

- $50 \mathrm{FF}$ - form factor, characterized as macro-fiber (Figure 1);

Thickness: $0.9 \mathrm{~mm}$;

- 110\%: elongation after fracture;

- Raw material: polypropylene monofilaments.

The water used was from the groundwater located in the town of Chapecó-SC.

\subsection{Mixtures}

The pervious concrete tests were conducted with five distinct mixtures, all prepared based on the suggestions of Polastre and Santos [28]; Merighi et al. [3] and Teixeira and Fortes [12]. According to these researchers, the pervious concrete must have an aggregate to cement ratio of 4 and 4.5 to 1 , a sand to cement ratio between 0 and 1 , and $w / c$ ratio between 0.27 and 0.40 . The reference mixture was developed based on these studies.

Based on mixture A, 04 other mixtures were studied with the addition of sand and gravel 0 , as shown in table 3. Preliminary tests showed the need to increase the $\mathrm{w} / \mathrm{c}$ ratio in mixtures $D$ and $E$, this fact is explained by the greater presence of fine aggregates. It is worth noting that it was chosen to limit the additive to $1 \%$ of the cement weight. 
Table 3

Summary of the mixtures

\begin{tabular}{ccccccc} 
& \multicolumn{5}{c}{ Mixture } \\
\hline Material & A & B & C & D & E \\
\hline Cement & 1 & 1 & 1 & 1 & 1 \\
Gravel 1 & 4 & 4 & 1 & 3 & 3 \\
Gravel 0 & - & - & 0.5 & 1.3 & 1.3 \\
Medium sand & - & 0.5 & 0.5 & 1 \\
Additive & $1 \%$ cement weight & $1 \%$ cement weight & $1 \%$ cement weight & $1 \%$ cement weight & $1 \%$ cement weight \\
W/C ratio & 0.25 & 0.25 & 0.25 & 0.30 & 0.35 \\
\hline
\end{tabular}

\subsection{Addition of fibers}

The definition of the mixture of a pervious concrete with the addition of polypropylene fibers was based on studies by Reyes and Torres [30]. Based on mixture (D), which had a good ratio between the strength and permeability properties, three additions with different levels of polypropylene fibers were performed:

- Small addition of fibers (mixture D1): $1 \mathrm{~kg} / \mathrm{m}^{3}$ (Figure 2);

- Medium addition of fibers (mixture D2): $2 \mathrm{~kg} / \mathrm{m}^{3}$;

- Large addition of fibers (mixture D3): $4 \mathrm{~kg} / \mathrm{m}^{3}$.

\subsection{Permeability}

The permeability test was performed based on the experiment conducted by Neithalath et. al [31]. According to the same authors, the equipment must contain a tube of transparent material (containing the specimen of $15 \mathrm{~cm}$ in height) so that it is possible to visualize the flow traveled by the water when it is discharged (Figure 3).

The transparent tube, which is fitted above the location where the concrete is coupled, must have a slightly larger diameter that allows for the fitting, and this fitting should be sealed to prevent water from leaking at this spot. Below the container holding the concrete, there is a horizontal tube of $50 \mathrm{~mm}$ in diameter, which in its middle part has a valve to control the water, and it is immediately followed by a vertical tube, which is $10 \mathrm{~mm}$ above the concrete specimen. Still according to Neithalath et al. [31], the test must be performed with the addition of water until the concrete becomes saturated, reach-

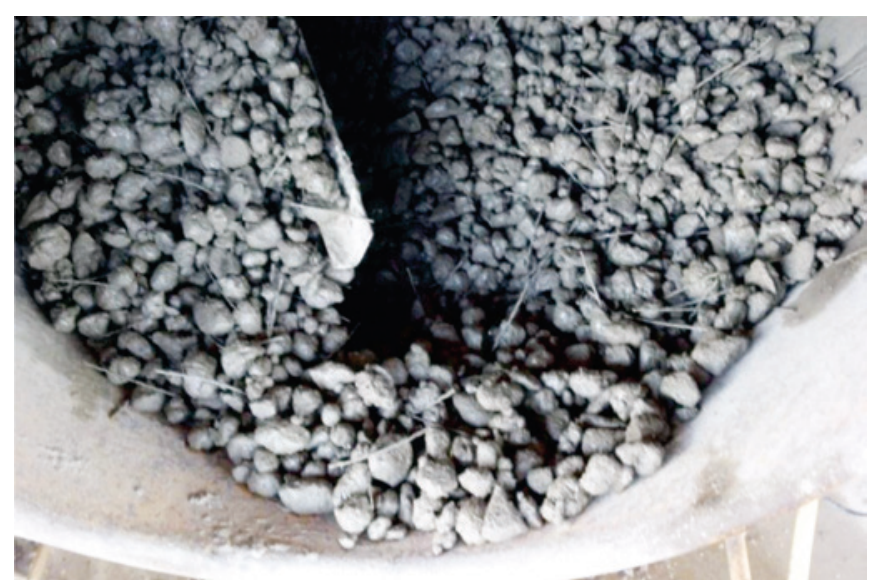

Figure 2

Appearance of the pervious concrete in mixture D1 ing the maximum level in the vertical tube, which is $1 \mathrm{~cm}$ below the specimen. The valve must then be closed and topped off with water until the $290 \mathrm{~mm}(\mathrm{HO})$ mark above the horizontal tube. Once it is filled with water, the valve is opened and the time is measured until the 70 $\mathrm{mm}$ mark $(\mathrm{H} 1)$ is reached. This procedure must be repeated 3 times and the arithmetic mean between the obtained values must be taken. The permeability is obtained through Darcy's law, shown below:

$k=\frac{a \cdot L}{A \cdot \Delta t} \cdot \ln \left(\frac{h 0}{h 1}\right)$

Where:

k: Permeability coefficient, in $\mathrm{cm} / \mathrm{s}$;

a: Inner area of the reservoir, in $\mathrm{cm}^{2}$;

A: Area of the concrete sample, in $\mathrm{cm}^{2}$;

$\mathrm{L}$ : Height of the specimen, in $\mathrm{cm}$;

h0: Initial water height, in $\mathrm{cm}$;

h1: Final water height, in $\mathrm{cm}$;

$\Delta \mathrm{t}$ : Percolation time of the water from point $\mathrm{h} 0$ to $\mathrm{H} 1$, in seconds. Some changes were made in the test regarding the basic procedure, namely:

- Pervious concrete specimen of $20 \mathrm{~cm}$ in height;

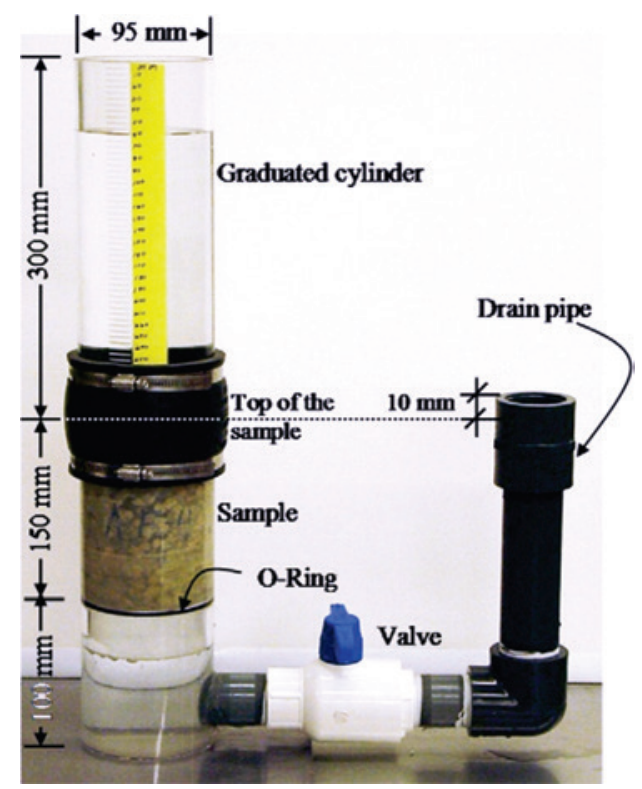

Figure 3

Permeameter model used 


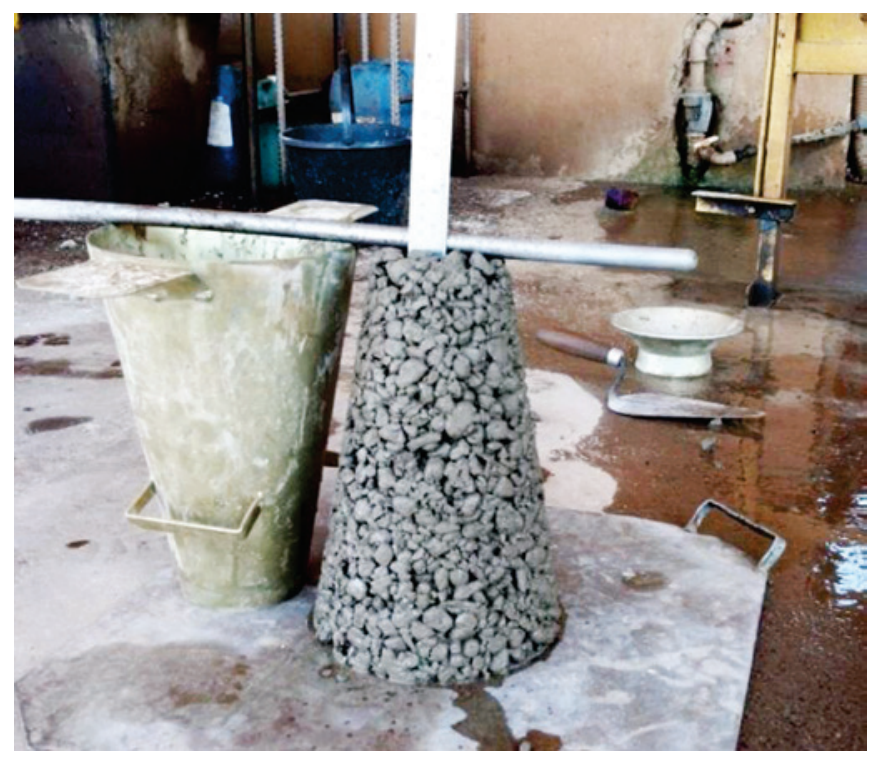

Figure 4

Slump test with zero slump

- The specimen is coupled to a PVC pipe of $100 \mathrm{~mm}$ in diameter

- The smaller pipe was made of PVC and was $25 \mathrm{~mm}$ in diameter;

- The ball valve used had $25 \mathrm{~mm}$ in diameter.

\section{Results and discussion}

\subsection{Results and analysis of aggregates}

A fineness modulus of 6.94 and a maximum size of $19 \mathrm{~mm}$ was found for the gravel 1 . Its bulk density was $1,511.7 \mathrm{~kg} / \mathrm{m}^{3}$. A fineness modulus of 5.77 and a maximum size of $9.5 \mathrm{~mm}$ was found for the gravel 0 . Its bulk density was $1,533.7 \mathrm{~kg} / \mathrm{m}^{3}$. A fineness modulus of 2.36 and a maximum size of $4.8 \mathrm{~mm}$ was found for the sand. Its bulk density was $1,617.8 \mathrm{~kg} / \mathrm{m}^{3}$ and the particle-size distribution ranked it as medium sand - zone 3 .

\subsection{Properties of the mixtures without fiber}

\subsubsection{Slump test}

In order to examine the consistency of the pervious concrete, a

\section{Table 4}

Axial compression strength

\begin{tabular}{cccc}
\hline Mixtures & \multicolumn{2}{c}{$\begin{array}{c}\text { Strength } \\
\text { (MPa) }\end{array}$} & $\begin{array}{c}\text { \% at 28 days } \\
\text { in relation to } \\
\text { the reference } \\
\text { mixture }\end{array}$ \\
\cline { 2 - 4 } & $\mathbf{7}$ days & $\mathbf{2 8}$ days & $100 \%$ \\
\hline A: $(1: 4: 0: 0)$ (reference) & 1.16 & 2.58 & $94.6 \%$ \\
B: $(1: 4: 0: 0.5)$ & 1.47 & 2.44 & $164.3 \%$ \\
C: $(1: 4: 1: 0.5)$ & 2.56 & 4.24 & $158.9 \%$ \\
D: $(1: 3: 1.3: 0.5)$ & 2.60 & 4.10 & $180.6 \%$ \\
E: $(1: 3: 1.3: 1)$ & 4.31 & 4.66 & \\
\hline
\end{tabular}

Table 5

Split tensile strength at 28 days

\begin{tabular}{ccc}
\hline Mixture & $\begin{array}{c}\text { Split tensile } \\
\text { strength } \\
\text { (MPa) }\end{array}$ & $\begin{array}{c}\text { Split tensile } \\
\text { strength } \\
\text { (MPa) }\end{array}$ \\
\hline A: $(1: 4: 0: 0)$ & 0.54 & $100 \%$ \\
(reference) & 0.36 & $66.7 \%$ \\
B: $(1: 4: 0: 0.5)$ & 1.94 & $359.3 \%$ \\
C: $(1: 4: 1: 0.5)$ & 1.92 & $355.6 \%$ \\
D: $(1: 3: 1.3: 0.5)$ & 2.59 & $479.6 \%$ \\
E: $(1: 3: 1.3: 1)$ & & \\
\hline
\end{tabular}

slump test was performed (Figure 4) and all tests found a slump of 0 (zero) $\mathrm{cm}$. The ACl 522R-06 standard[4] classifies pervious concrete as concrete with zero slump.

Given the fact that this concrete has little fineness in its dosage, a low w/c ratio and little paste, it was low workability, requiring greater care in handling and vibration, with the use of powered vibrations being suggested by $\mathrm{ACl} 522 \mathrm{R}-06$ [4]. Considering that the use in pavements is one of the main applications of pervious concrete, the density study with a plate compactor or roller may be viable, improving the mechanical properties, although the permeability should be checked.

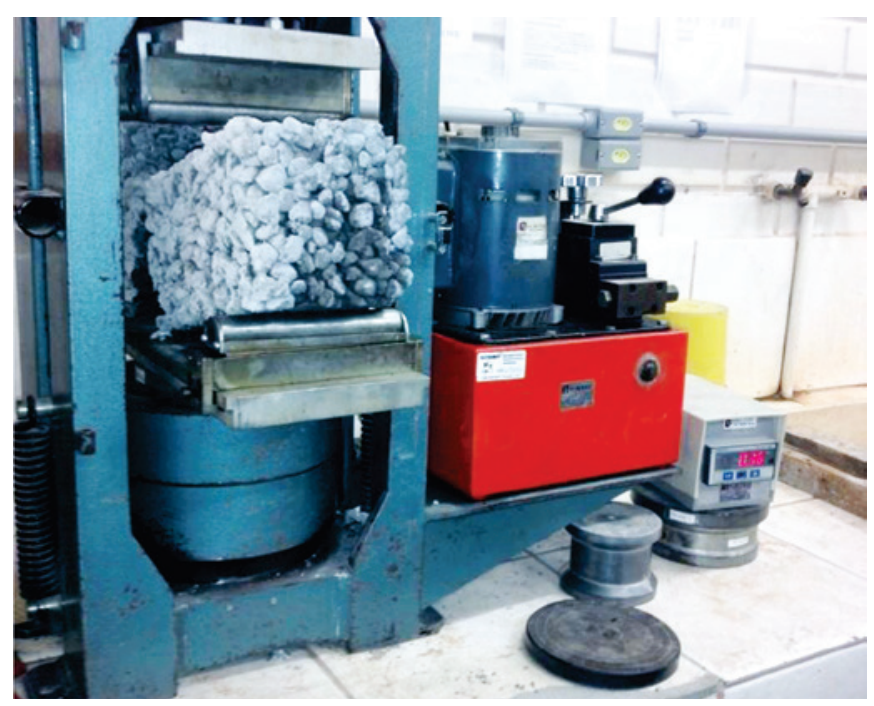

Figure 5

Flexural strength test

Table 6

Flexural strength at 28 days

\begin{tabular}{ccc}
\hline Mixture & $\begin{array}{c}\text { Flexural strength } \\
(\mathrm{MPa})\end{array}$ & $\begin{array}{c}\% \text { in relation to the } \\
\text { reference mixture }\end{array}$ \\
\hline A: $(1: 4: 0: 0)$ & 1.70 & $100 \%$ \\
(reference) & 2.45 & $144.1 \%$ \\
B: $(1: 4: 0: 0.5)$ & 2.52 & $148.2 \%$ \\
C: $(1: 4: 1: 0.5)$ & 2.49 & $146.5 \%$ \\
D: $(1: 3: 1.3: 0.5)$ & 6.35 & $373.5 \%$ \\
E: $(1: 3: 1.3: 1)$ & &
\end{tabular}


Table 7

Permeability results

\begin{tabular}{cc}
\hline Mixture & $\mathrm{K}(\mathrm{cm} / \mathrm{s})$ \\
\hline A: $(1: 4: 0: 0)$ (reference) & 0.093 \\
B: $(1: 4: 0: 0.5)$ & 0.121 \\
C: $(1: 4: 1: 0.5)$ & 0.103 \\
D: $(1: 3: 1.3: 0.5)$ & 0.110 \\
E: $(1: 3: 1.3: 1)$ & 0.078 \\
\hline
\end{tabular}

\subsubsection{Axial compression}

As can be seen in Table 4, mixture $\mathrm{E}$ had the greatest strength at 7 and 28 days. In general, the addition of sand and gravel 0 increases the compression strength, which was already expected, although the water/cement ratio had to be increased in mixtures (D) and (E) from 0.25 to 0.30 and 0.35 , respectively. This increase of the $\mathrm{w} / \mathrm{c}$ ratio was needed to be able to get a more homogeneous mixture because of the finer aggregate, since the preliminary concrete mixtures proved difficult to handle.

\subsubsection{Split tensile strength}

As can be seen in Table 5, the greatest strength in this test was achieved by mixture $\mathrm{E}$, with a value of $2.59 \mathrm{MPa}$. The addition of sand and gravel 0 increased the split tensile strength, with relevant gains especially when gravel 0 was added to the mixtures. This fact is due to the tighter packing of the concrete structure with the presence of finer aggregates.

\subsubsection{Flexural strength}

The trend of the previous test remained, with a considerable gain in mixture $E$, especially with the observation that the ruptured specimens of mixture $E$ had a greater homogeneity than the other mixtures (Table 6). The flexural strength values (Figure 5) proved to be higher than the split tensile strength, with Batezini [14] also observing this trend with values up to 3 to 4 times higher. From the perspective of the ABNT [5] and with the exception of mixture A, all mixtures had an adequate flexural strength $(\geq 2.0 \mathrm{MPa})$ for light traffic areas, with a minimum thickness of $10 \mathrm{~cm}$.

\subsubsection{Permeability}

The results in table 7 reveal that mixture $E$ had the lowest

\section{Table 8}

Axial compression strength after the addition of fibers at 28 days

\begin{tabular}{ccc}
\hline Mixture & $\begin{array}{c}\text { Strength } \\
\text { (MPa) }\end{array}$ & $\begin{array}{c}\text { \% at 28 days } \\
\text { in relation to } \\
\text { the reference } \\
\text { mixture }\end{array}$ \\
\hline D: reference - no fibers & 4.10 & $100 \%$ \\
D1: with fibers $1 \mathrm{~kg} / \mathrm{m}^{3}$ & 3.46 & $84.4 \%$ \\
D2: with fibers $2 \mathrm{~kg} / \mathrm{m}^{3}$ & 3.69 & $90.0 \%$ \\
D3: with fibers $4 \mathrm{~kg} / \mathrm{m}^{3}$ & 2.32 & $56.6 \%$ \\
\hline
\end{tabular}

permeability as a result of its lower voids content, resulting from the increased presence of sand and gravel 0 . On the other hand, it would be expected that mixture A would have one of the best permeabilities for having no sand in its dosage, but this trend was not manifested and the mixture with the best results was mixture B. From the perspective of the ABNT [5] and with the exception of mixtures $A$ and $E$, all other mixtures reached the recommended minimum permeability values.

Based on the results above, one can conclude that the addition of sand to pervious concretes for pavements molded on site is beneficial, increasing their mechanical strength. The reduction in permeability to values below those recommended by NBR 16416 (ABNT [5]) is only observed when the levels of sand exceed $35 \%$.

\subsection{Properties of the mixtures with fiber}

\subsubsection{Slump test}

The slump test was performed, but there was no determination of values for this test because the concrete presented a slump close to zero, suitable for paving with powered mechanical compaction.

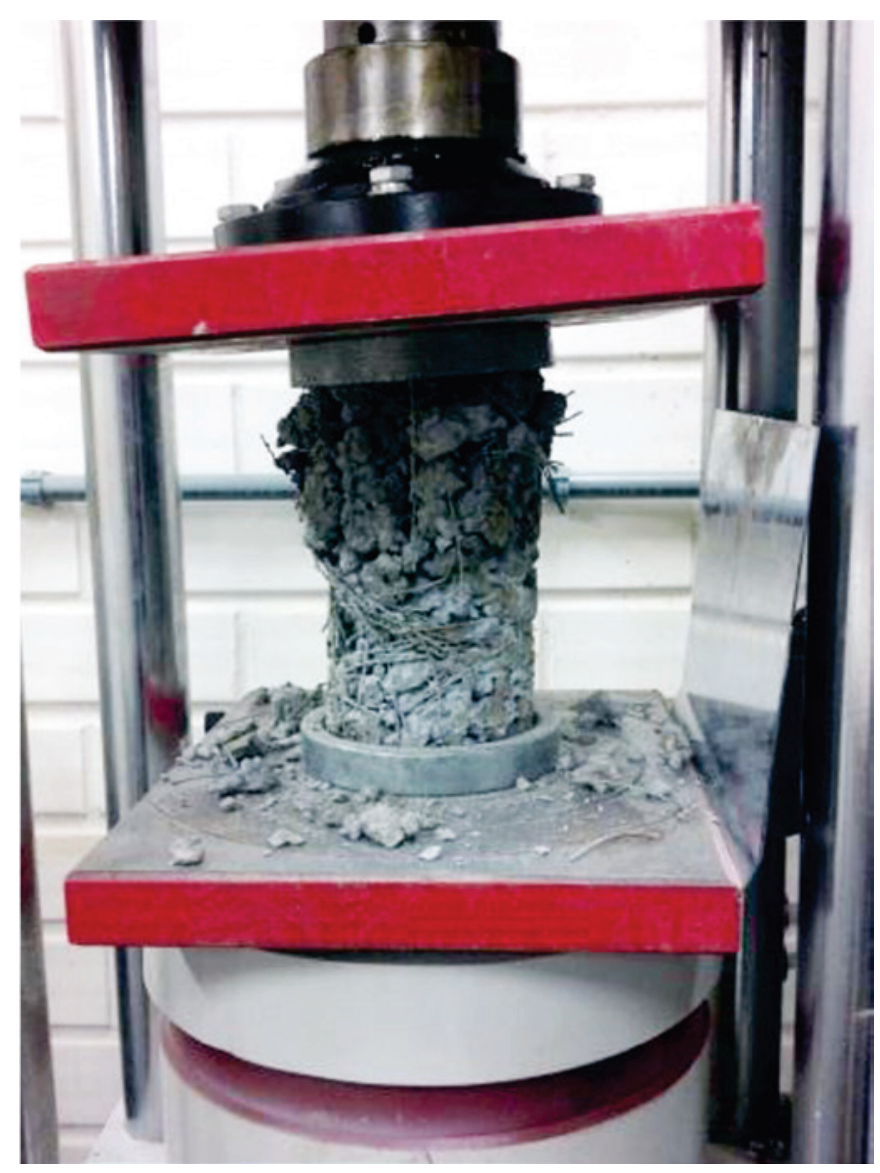

\section{Figure 6}

Rupture under axial compression of pervious concrete with fibers 


\section{Table 9}

Split tensile strength after the addition of fibers at 28 days

\begin{tabular}{ccc}
\hline Mixture & $\begin{array}{c}\text { Strength } \\
\text { (MPa) }\end{array}$ & $\begin{array}{c}\text { \% at 28 days } \\
\text { in relation to } \\
\text { the reference } \\
\text { mixture }\end{array}$ \\
\hline D: reference - no fibers & 1.92 & $100 \%$ \\
D1: with fibers $1 \mathrm{~kg} / \mathrm{m}^{3}$ & 0.82 & $42.7 \%$ \\
D2: with fibers $2 \mathrm{~kg} / \mathrm{m}^{3}$ & 1.46 & $76.1 \%$ \\
D3: with fibers $4 \mathrm{~kg} / \mathrm{m}^{3}$ & 1.43 & $74.5 \%$
\end{tabular}

\subsubsection{Axial compression strength}

Table 8 shows the results for the axial compression test carried out at 28 days (Figure 6). As can be seen, there was a decrease in the compression strength with the addition of fibers. This fact can only be explained after the analysis of the ruptured specimens. The fibers hindered the kneading process of the concrete, which by its very nature already had a workability of almost zero. A blistering of fibers could be observed in certain parts of the concrete, generating a weak link where fracture zones were created. This suggests that the fiber-addition process requires very great care, in addition to a kneading process that makes the mixture more homogeneous.

\subsubsection{Split tensile strength}

The concrete with the highest split tensile strength was mixture D2, with a value of $1.46 \mathrm{MPa}$ at 28 days. The fact that mixture D1 had a smaller amount of fibers in its mixture than mixtures D2 and D3 interfered to provide a small gain in strength, getting close to the strength of the reference mixture $D$, which did not have fibers in its mixture. The relationship between the values of mixtures D3 and D2 follows the same explicit logic of the axial compression, with D3 having less strength than D2 despite having twice the fibers (Table 9).

\subsubsection{Flexural strength}

In the case flexural strength, the best result at 28 days was achieved by mixture D3 (2.92 MPa). Based on table 10, one can conclude that the increased strength occurred in conjunction with the increased addition of fibers, and that unlike what occurred with compression, the D3 mixture, which has the largest amount of fi-

\section{Table 10}

Flexural strength after the addition of fibers at 28 days

\begin{tabular}{ccc}
\hline Mixture & $\begin{array}{c}\text { Strength } \\
\text { (MPa) }\end{array}$ & $\begin{array}{c}\text { \% at 28 days } \\
\text { in relation to } \\
\text { the reference } \\
\text { mixture }\end{array}$ \\
\hline D: reference - no fibers & 2.49 & $100 \%$ \\
D1: with fibers $1 \mathrm{~kg} / \mathrm{m}^{3}$ & 1.26 & $50.6 \%$ \\
D2: with fibers $2 \mathrm{~kg} / \mathrm{m}^{3}$ & 2.74 & $110.0 \%$ \\
D3: with fibers $4 \mathrm{~kg} / \mathrm{m}^{3}$ & 2.92 & $117.3 \%$ \\
\hline
\end{tabular}

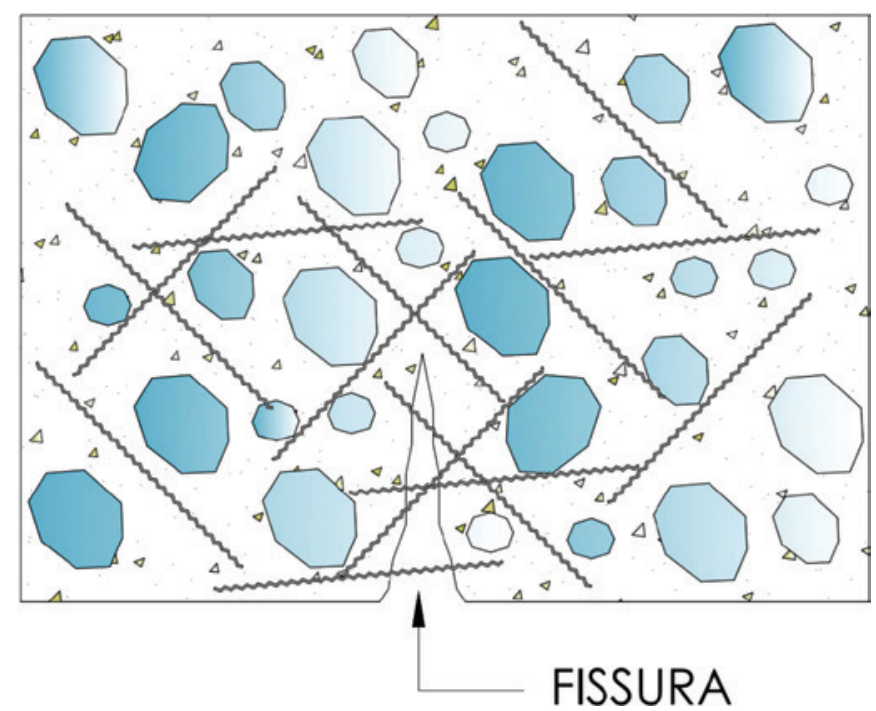

Figure 7

Macro-fibers acting in the crack region in the flexural strength

bers $\left(4 \mathrm{~kg} / \mathrm{m}^{3}\right)$, had the highest flexural strength. With the exception of mixture $\mathrm{D} 1$, the mixtures comply with the minimum specified by the ABNT [5] standard.

The improvement in the flexural strength behavior with the addition of fibers can be explained in the post-cracking behavior, when the macro-fibers form a seam in the crack region, acting like a reinforcement, as can be seen in Figure 7.

\subsubsection{Permeability}

As we can see in Table 11, the permeability coefficient was highest for mixture D1. The mixtures with the addition of $2 \mathrm{~kg} / \mathrm{m}^{3}$ and $4 \mathrm{~kg} /$ $\mathrm{m}^{3}$ of polypropylene fibers had lower permeability. Mixture D3 had the lowest permeability $(\mathrm{k}=0.0996 \mathrm{~cm} / \mathrm{s})$, while mixture D1 had a permeability of $0.1237 \mathrm{~cm} / \mathrm{s}$, this being the highest value obtained among the mixtures.

According to NCPTC [10], the 3 tested mixtures fall within the permeability standards for pervious concrete. And mixture $\mathrm{B}$, which showed the highest values for permeability $(0.121 \mathrm{~m} / \mathrm{s})$, can be compared to the mixture by Kajio et al. [15], which obtained values between 0.025 to $0.178 \mathrm{~cm} / \mathrm{sec}$. According to the ABNT [5], all the other mixtures have the minimum recommended permeability.

\section{Table 11}

Permeability of concretes with fiber

\begin{tabular}{ccc}
\hline Mixtures & $\mathbf{k}(\mathbf{c m} / \mathbf{s})$ & $\begin{array}{c}\% \text { in relation to } \\
\text { the reference } \\
\text { mixture }\end{array}$ \\
\hline D: reference - no fibers & 0.110 & $100 \%$ \\
D1: with fibers $1 \mathrm{~kg} / \mathrm{m}^{3}$ & 0.124 & $112.7 \%$ \\
D2: with fibers $2 \mathrm{~kg} / \mathrm{m}^{3}$ & 0.107 & $97.3 \%$ \\
D3: with fibers $4 \mathrm{~kg} / \mathrm{m}^{3}$ & 0.100 & $90.9 \%$ \\
\hline Source: developed by the authors & &
\end{tabular}

Source: developed by the authors 
When it comes to pervious concrete pavements molded on site, one can see that the addition of fibers improves the main property to be considered for its use by NBR 16416 (ABNT [5]), which is its flexural strength. The reduction in permeability with the increase in fiber content indicates that the levels should remain below $4 \mathrm{~kg} / \mathrm{m}^{3}$.

\section{Concluding remarks}

The objective of this work was to study pervious concrete mixtures for use in pervious concrete floors molded on site, checking the compression strength, split tensile strength, flexural strength and permeability properties in mixtures without the addition of fibers, but with the addition of gravel 0 and sand to the reference mixture that contained only gravel 1 . Subsequently, the influence of the addition of polypropylene fibers on the properties described above was tested for one of the mixtures that contained gravel 0 and sand. The following can be observed:

1) There were considerable gains in strength when gravel 0 was added in addition to the sand, with the exception of mixture B, which might have had mixing and/or molding problems, and permeability began to decrease in mixture $\mathrm{E}$, when the gravel 0 and sand to gravel 1 ratio reached the range of $43 \%$. In mixtures $C$ and $D$, this ratio was $27 \%$ and $37 \%$, which indicates that the addition of sand is beneficial for the mechanical properties, without affecting permeability up to a certain level, in the order of $35 \%$

2) All concrete mixtures, with or without fibers, had permeability coefficients within the recommended levels, ranging from 0.124 $\mathrm{cm} / \mathrm{s}$ to $0.078 \mathrm{~cm} / \mathrm{s}$, considered to be whithin the acceptable range according to ACI 522R-06[4] and NCPTC [10]. If the permeability required by NBR 16416 (ABNT [5]) is considered, then only the mixtures $A$ and $E$ failed to reach the minimum value.

3) For the compression strength, the values of the mixtures without fiber remained above the minimum value recommended by $\mathrm{ACl}$ 522R-06[4]. It should be noted that this requirement is not the parameter considered by NBR 16.416 (ABNT [5]).

4) The relationship between the split tensile strength and the flexural strength was between 50 and $77 \%$, near the standard studied by Batezini [14] for concrete without fibers, and with the trend holding for the concretes with fibers, therefore.

5) Despite the decrease in compression strength of the mixtures with the addition of fibers, their gains in tensile strength makes the use of fibers attractive, since flexural strength is the criterion that must be met for pervious concrete molded on site according to NBR 16416 (ABNT [5]), and for this criterion, all mixtures have adequate mechanical strength. This increase in flexural strength had already been observed by Hesami et al. [23]. Rehder et al. [27], who also cited the contribution of fibers to the flexing capacity, since long fibers (macro-fibers) with a length equal to or two-times greater than the maximum size of the aggregate, have the ability to "weave" the structure after the beginning of the crack during bending.

6) The values found for mechanical strength and the permeability coefficient for the mixtures $C, D$ and $E$ in the concrete without fibers, and in the mixtures with fiber, already suggest the possibility of their use on the pavement of areas for parking and with light traffic, with no more than the specification of the adequate thickness being required, as suggested by the ABNT [5]. However, in order for the specification of the thicknesses to decrease and become more attractive from an economic point of view (Batezini [14]), studies on the improvement of the mechanical strength, even with a loss in permeability, should be considered. In this sense, continued research is suggested, considering the study of variations in mechanical properties as a function of the variation of the compaction energy.

7) The addition of fibers to pervious concretes, which already brings with it the characteristic of the difficulty in kneading and homogenizing because of the high voids content, is a point that deserves attention to avoid the blistering of the fibers, which can reduce the mechanical strength.

8) The low consistency values indicate that, ideally, mechanical compaction should be used so that the mechanical properties are improved (Bonicelli et al. [18] ), suggesting the use of a plate compactor or roller.

\section{References}

[1] $\quad A B C P-$ Associação Brasileira de Cimento Portland. Projeto Técnico: Pavimento permeável. São Paulo, 2013.

[2] MARCHIONI, M.; SILVA, C. O.;VAQUERO Y MAYOR, A.. Conceitos e requisites para pavimentos de concreto permeável. Associação Brasileira de Cimento Portland, São Paulo, 2011

[3] MERIGHI, João Virgilio; FORTES, Rita Moura; BANDEIRA, Alex. Estudo de propriedades do concreto poroso aplicado a pavimentação. In: IBRACON, 2006, Rio de Janeiro - RJ. Anais do $48^{\circ}$ Congresso Brasileiro do Concreto. São Paulo - SP, 2006.

[4] ACl 522R-06 - American Concrete Institute. Pervious Concrete. Michigan, 2006

[5] ABNT - Associação Brasileira de Normas Técnicas. NBR 16.416: Pavimentos permeáveis de concreto- Requisitos e procedimentos. Rio de Janeiro, 2015

[6] RODRIGUES, Públio Penna Firme; MONTARDO, Julio P.. A Influência da Adição de Fibras de Polipropileno nas Propriedades dos Concretos para Pisos e Pavimentos. In: IBRACON, 2002, Belo Horizonte - MG. Instituto Brasileiro do Concreto - 44 Congresso Brasileiro. Belo Horizonte - MG, 2002.

[7] MCCAIN, George N.; DEWOOLKAR, Mandar M. Porous Concrete Pavements: Mechanical and Hidraulic Properties. School of Engineering the University of Vermont. Burlington, USA, 2010

[8] SHU, X.; HUANG, B.; WU, H,; DONG, Q.; BURDETTE, E.. Performance comparison of laboratory and field produced pervious concrete mixtures. Construction and Building Materials, v. 25, p.3187-3192, 2011.

[9] LYAN, C.; ZHUGE, Y.. Optimum mix design of enhanced permeable concrete - An experimental investigation. Construction and Building Materials, v. 24, p.2664-2671, 2010.

[10] NCPTC - NATIONAL CONCRETE PAVEMENT TECHNOLOGY CENTER. Mix Design Development for Pervious Concrete in Cold Weather Climates. lowa Department of Transportation. lowa Concrete Paving Association. 25. fev. 2006. 
[11] ENVIROMENTAL PROTECTION AGENCY. Storm Water Technology Fact Sheet, Porous Pavement. EPA 832-F-99023 Office of Water, Washington, D.C. 1999

[12] TEIXEIRA, B. C. S.; FORTES, R. M. Estudo da Dosagem de Concreto Poroso Aplicado a Pavimentação (Study of Pervious Concrete Dosage For Use In Pavements). In: CONINFRA - Anais do Congresso De Infraestrutura De Transportes, São Paulo. 2009: 12 p.

[13] IBRAHIM, A.; MAHMOUD, E; YAMIN, M; PATIBANDLA, V. C. Experimental study on Portland cement pervious concrete mechanical and hydrological properties. Construction and Building Materials, v. 50, p.524-529, 2014.

[14] BATEZINI, R.. Estudo preliminar de concreto permeáveis como revestimento de pavimento para áreas de veículos leves. 2013. 133 p. Dissertação (Mestrado) - Mestrado de Engenharia Civil, Escola Politécnica da Universidade de São Paulo, São Paulo, 2013.

[15] KAJIO, S.; TANAKA, S.; TOMITA, R.; NODA, E.; HASHIMOTO, S. Properties of Porous Concrete with High Strenght. Proceedings $8^{\text {th }}$ International Symposium on Concrete Roads, Lisboa, p. 171-177, 1988.

[16] TENNIS, P. D.; LEMMING, M. L.; AKERS, D. J. Pervious Concrete Pavements, Skokie, Illinois: Portland Cement Association, 2004

[17] COSIC, K.; KORAT, L; DUCMAN, V.; NETINGER, I.. Influence of aggregate type and size on properties of pervious concrete. Construction and Building Materials, v. 78, p.6976, 2015

[18] BONICELLI, A.; GIUSTOZZI, F; CRISPINO, M.. Experimental study on the effects of fine sand addition on differentially compacted pervious concrete. Construction and Building Materials, v. 91, p.102-110, 2015.

[19] MAgUeSVARI, M Uma; NARASIMHA, V.L.. Studies on Characterization of Pervious Concrete for Pavement Applications. Procedia - Social and Behavioral Sciences, ed.104, p. 198-207, 2013.

[20] SENISSE, Juliana; DAL MOLIN, D. C. C. A influência de microfibras de polipropileno e de aditivo superplastificante nas propriedades de concretos com níveis de resistência semelhantes. In: IBRACON, 2011, Florianópolis - SC. Anais do $53^{\circ}$ Congresso Brasileiro do Concreto. Porto Alegre - RS, 2011.

[21] PERRONE, Vitor Cury et al. Estudo do comportamento à flexão de compósitos cimentícios reforçados com fibras de polipropileno de alta tenacidade. In: IBRACON, 2011, Florianópolis - SC. Anais do $53^{\circ}$ Congresso Brasileiro do Concreto. Porto Alegre - RS, 2011.

[22] GESOGLU, M.; GÜNEYISI, E; KHOSHNAW, G.; IPEK, S.. Investigating properties of pervious concretes containing waste tire rubbers. Construction and Building Materials, v. 63, p.206-213, 2014.

[23] HESAMI, Saeid.; AHMADI, Saeed; NEMATZADEH, Mahdi. Effects of rice husk ash and fiber on mechanical properties of pervious concrete pavement. Construction and Building Materials, ed. 53, p. 680-691, 2014.

[24] AMARAL JUNIOR, Josué Coelho. Avaliação da influência da adição de fibras poliméricas nas propriedades térmicas e mecânicas do concreto. Dissertação (Mestrado) - Programa de Pós Graduação em Engenharia de Materiais, Centro Federal de Educação Tecnlógica de Minas Gerais, Belo Horizonte, 2016.

[25] LUCENA, Júlio César Tavares. Concreto reforçado com fibras de polipropileno: estudo de caso para aplicação em painel alveolar de parede fina. Dissertação (Mestrado) - Programa de Pós Graduação em Engenharia Civil. Escola de Engenharia de São Carlos, São Carlos, 2017.

[26] GUIMARÃES, Diego; SILVA FILHO, Luiz C. P. da; PACHE$\mathrm{CO}$, Alexandre R. Pisos industriais em concreto armado: determinação de teores ótimos de fibras de aço e polipropileno em ensaios mecânicos. In: IBRACON, 2011, Florianópolis - SC. Anais do $53^{\circ}$ Congresso Brasileiro do Concreto. Porto Alegre - RS, 2011.

[27] REHDER, Benjamin.; BANH, Kingsten; NEITHALATH, Narayanan. Fracture behavior of pervious concretes: The effects of pore structure and fibers. Engineering Fracture Mechanics, ed. 118, p. 1-16, 2014.

[28] POLASTRE, B.; SANTOS, L. D. Concreto Permeável. Faculdade de Arquitetura e Urbanismo-USP. São Paulo: $2^{\circ}$ Semestre de 2006. Disponível em: <http://www.usp.br> Acesso em: 04 de maio de 2013.

[29] SALES, T. L. Pavimento Permeável com Superfície em Blocos de Concreto de Alta Porosidade. 2008. 188 p. Dissertação (Mestrado) - Mestrado de Engenharia Civil, Departamento de Programa de Pós-graduação em Engenharia, Universidade Federal de Santa Catarina, Florianópolis, 2008.

[30] REYES, Fredy; TORRES, Andrés. Efecto de las fibras plasticas en la flexion de estructuras de pavimentos drenantes. Ingeniería de Construcción, Chile, v. 17, n. 2, p.93-102, 2002.

[31] NEITHALATH, Narayanan.; SUMANASOORIYA, Milani S; DEO, Omkar. Characterizing pore volume, sizes, and connectivity in pervious concretes for permeability prediction. Materials Characterization, ed. 61, p. 802-813, 2010. 